\title{
Contents Vol. 42 (1-3)
}

Editoria

Papers presented at Technical Session of 1965 Annual Meeting

The Middle-aged Mensurationist

George W. Thomson - - - - - - - - - 6

Regulation of Wood Measurement Practices for the Future

Henri Simard - - - - - - - - - - - 14

Current Scaling Practices and Developments in British Columbia
A. R. Fraser and C. J. Highsted - - 18

Wood Measurement Concepts in Ontario

J. Barron - - - - - - - - - - - - 23

The Measurement of Forest Products in Canada: Past, Present and Future Historical and Legislative Background

J. W. Ker - - - - - - - - - - - -

A Simulation Model for studying the Effect of $\overline{-}$ Stand Structures on Harvesting Pattern

R. M. Newnham

The Canada Land Inventory of ARDA

R. J. McCormack

Problems in Research Communication G. F. Weetman

Forest Fire Control-Some Modern Aspects

G. S. Chester -

A Field Trial of Weight Scaling Alan Moss

A Frost Hardiness Study of Six Coniferous Species

C. Glerum J. I Farrar and R I. MoClure

Prevention of Insect-caused Seed Loss in Douglas-fir with Systemic

Insecticides

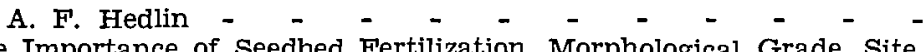

Relative Importance of Seedbed Fertilization, Morphological Grade, Site,

Provenance,

J. H. G. Smith, A. Kozak, O. Sziklai, and J. Walters - - - 83

Can Fertilization Reduce Planting-check of Douglas fir?

J. H. G. Smith, O. Sziklai, and J. D. Beaton - - - - - 87

News and Notes

In Appreciation of Contributions of two Soviet Scientists - -90 Visiting Tree Breeding Stations in Scandinavia and Finland - 94 Meeting of National Committee on Forest Land - - - $\quad$ - 97 Obituaries Comments on Canada Land Inventory - - - - - - 98

R. C. St. Clair Robert Barras -

Grow a Maximum of Cellulose per Acre - - - - - -

Grow Large Trees and High Volumes per Acre - - - - 101

Reviews A Field Forestry View on Research - _ - - - - - 103

Forest Ecological Studies on Drained Peat Land - _ - - 104 Economic Principles of Forest Transportation - - - - 105 Forestry in Communist China - - - - - - Association of B.C. Foresters' Elections - $\quad$ - $\quad$ - $\quad$ - $\quad$ - 107 Institute Affairs

C.IF. Salary Survey

Employment Wanted Membership Changes 
Editorial Article - - - - -

The Growth and Absorption of Nutrients by Fertilized and Unfertilized White Spruce Seedlings

K. A. Armson

Effects of Defoliation on Young Upland Tamarack in Manitoba

W. G. H. Ives and L. D. Nairn - - - - - - - 137

Comparative Survival and Growth of Five Conifers Ridge-planted on a Wet Site

J. D. MacArthur - - - - - - - - - - 143

Loss of Nitrogen from the Forest Floor by Burning

H. Knight

Proposed Methodology for an Inventory and Classification of Land for Recreational Use

G. Taylor and C. W. Thomson - - - - - - $\quad 153$

Dothistroma Needle Blight of Pines in British Columbia

A. K. Parker and D. G. Collis - - - - - - - 160

Private Woodlands, the Suburban Forest and Aesthetic Timber Harvesting

L. S. Hamilton - - - - - - - - - - 162

Winter Scarification and White Spruce Regeneration, Saskatchewan

J. G. Gilmour - - - - - - - - - - - 167

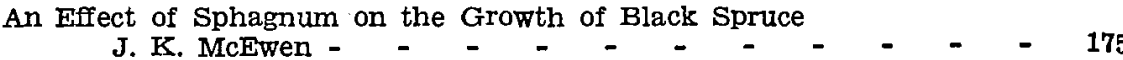

Wildland Inventory and Mapping

D. S. Lacate - - - - - - - - - - - 184

News and Notes

Tree breeders and geneticists to meet in Vancouver - - - - 195

1966 meeting on bibliography and terminology - - - - - 195

A bear-proof raingauge for wildland watersheds - - - - - 196

SAF meeting in Seattle - - - - - - - - - - 197

Extensive hail damage in Northern Manitoba - - - - - 198

International training course on the use of radioisotopes and -199

radiation in forestry research - - - - - $-\quad-\quad-199$

1967 IUFRO meeting -
Background to adoption of Ontario Log Rule -
-

Obituary

Andre Linteau - - - - - - - - - - - 203

For the Sake of Argument

Crowding can improve wood quality - - - - - - -204

Grow timber for the greatest total benefit - - - - - - 204

Grow small or large trees? - - - - - - - - - 206

A further comment by Vincent - - - - - - - - 207

Reviews

Holz Mess Lehre - - - - - - - - - -

The ecological viewpoint - $-\quad$ - $\quad$ - $\quad-\quad-\quad-209$

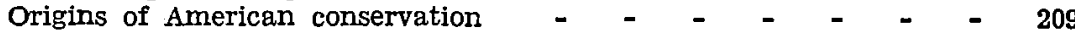

An economic appraisal of sustained yield forest management - $\quad 210$

Product yield and value, financial rotations, and biological

relationships of good site Douglas fir - _ _ _ _ - 211

2, 4-D, 2, 4, 5T, and related chemicals for woody plant control
in the Southeastern United States _ _

Current Publications - - - - - - - - - - - 212

Employment - - - - - - - - - - - - - 216

Membership Changes - - - - - - _ - - - - 216 
The Growth of the Soviet Lumber Industry and Exports

R. M. Bone

Diameter Distribution of Balsam Fir on Two Site Types in Quebec

To Thin or Not to Thin: Some Nordic Observations on the Question

Ake Wiksten

Development of a White Pine Underplantation in Thinned and Unthinned Aspen

J. R. Clements

The Effect of Leaf Litter upon Establishment of White Spruce

Beneath Paper Birch

R. A. Gregory

Root Pruning of Nursery Stock

R. E. Mullin

A Progress Report on Forest Nutrition Studies on Vancouver Island

E. C. Crossin, J. A. Marlow, and G. L. Ainscough - - 265

Forestry and the Urban Realm

E. M. Gould, Jr.

Profitability of Pruning White Pin

K. W. Horton

Relative Quality of the Major Forest Associations of the Southern

B.C. Interior for Growth of Lodgepole Pine, Engelmann Spruce, Douglas-fir, and Alpine Fir

News and Notes W. Stanek

Reviews

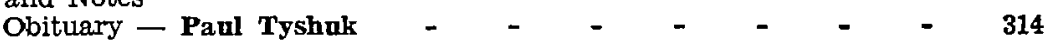

Economics of the Pulp and Paper Industry - $\quad-\quad-\quad-\quad-315$ Reforestation in Spain

Sake of Argument

Wide Spacing Results in Better Quality More Study of Scarification and Seed Dispersal Needed - - 318 Institute Affairs

C.I.F. Gold Medal Winners - $\quad$ - $\quad$ - $\quad$ - $\quad$ - $\quad$ Schlich Memorial Fund Award

Current Publications

Membership Changes

Employment

Continued on Page 332 